TITLE:

\title{
Some fluidized landslides triggered by the 2011 Tohoku Earthquake (Mw 9.0), Japan
}

\section{$\operatorname{AUTHOR}(\mathrm{S}):$}

Wang, Gonghui; Suemine, Akira; Zhang, Fanyu; Hata, Yoshiya; Fukuoka, Hiroshi; Kamai, Toshitaka

\section{CITATION:}

Wang, Gonghui ...[et al]. Some fluidized landslides triggered by the 2011 Tohoku Earthquake (Mw 9.0), Japan. Geomorphology 2014, 208: 11-21

ISSUE DATE:

2014-03-01

URL:

http://hdl.handle.net/2433/183219

\section{RIGHT:}

(C) 2013 Elsevier B.V.; This is not the published version. Please cite only the published version.; この論文は出版社版でありません。引用の際に は出版社版をご確認ご利用ください。 


\section{Some fluidized landslides triggered by the 2011 Tohoku Earthquake (M9.0), Japan}

Gonghui Wang ${ }^{\mathrm{a}^{*}}$, Akira Suemine ${ }^{\mathrm{a}}$, Fanyu Zhang ${ }^{\mathrm{b}}$, Yoshiya Hata ${ }^{\mathrm{c}}$, Hiroshi Fukuoka ${ }^{\mathrm{a}}$, Toshitaka Kamai ${ }^{\mathrm{a}}$

${ }^{a}$ Research Center on Landslides, Disaster Prevention Research Institute, Kyoto University, Gokasho, Uji, Kyoto, 611-0011, Japan

${ }^{\mathrm{b}}$ Department of Geological Engineering, Lanzhou University, Tianshui Road, 222, Lanzhou, 730000, P.R. China

${ }^{\mathrm{c}}$ Graduate School of Engineering, Osaka University, Yamada Oka 2-1, Suida, 565-0871, Osaka, Japan

* Corresponding author. Tel: +81-774-384115; Fax: +81-774-384300

E-mail address: wanggh@landslide.dpri.kyoto-u.ac.jp (G. Wang) 
1 Abstract

2 The 2011 Tohoku Earthquake off the Pacific coast of Japan generated a large tsunami and many landslides,

3 resulting in a great number of casualties. Although almost all casualties resulted from the tsunami, some

4 long-travel, fluidized small-scale landslides also killed 13 people. After the earthquake, we surveyed seven of

5 these catastrophic landslides triggered by the earthquake. We found that most of them have nearly identical

6 geological features, with slopes consisting of pyroclastic deposits formed at different times, and with a palaeosol

7 layer that outcropped in most cases after the landslide. Above the palaeosol there are layers of pumice and

8 scoria. The palaeosol had a natural moisture content of $\sim 160 \%$, and the pumice and scoria a moisture content of

$9 \sim 145 \%$. From field observations we concluded that the sliding surface originated in the very upper part of

10 palaeosol, and liquefaction occurred in both layers, resulting in the fluidization of displaced landslides. To

11 examine the trigger and movement mechanism of these landslides, we monitored the ground motion of one landslide area during the many aftershocks, and compared the results with records obtained by a national seismic

13 station nearby. We inferred that strong seismic motion occurred in the landslide area during the main shock. We

14 sampled the palaeosol and pyroclastic deposits, and performed undrained static/cyclic shear tests on the materials both in a saturated state and at natural moisture content. The results indicate that high pore-water pressure

16 generated, resulting in decreased shear strength even in samples with the natural moisture content. The shear strength of the palaeosol lowered to a very small value with continuous increase of shear rate, enabling the high mobility of the displaced landslide materials. 

contents, the post-failure behaviour of the landslide was inferred.

\section{Introduction} Region.

An earthquake of magnitude $9.0\left(M_{\mathrm{w}}\right)$ occurred at 14:46 JST on 11 March 2011, off the Pacific coast of the Tohoku Region, adjacent to the northeastern part of the Japanese mainland (Fig. 1). This "2011 Tohoku Earthquake" is the strongest one known to have hit Japan. The earthquake triggered an extremely powerful tsunami, causing many casualties (15,883 confirmed deaths, 2,656 missing, and 6,145 injured as of 9 August 2013, according to the Japanese National Police Agency) and severe destruction of infrastructure in the Tohoku

Many landslides were triggered by this earthquake in the wider Tohoku Region, with some concentrated in the southern part of Fukushima Prefecture, in hilly residential areas of Miyagi and Fukushima Prefectures, and on island areas of the Matsushima coast. Although the landslides were small for the magnitude of the earthquake (compared to those landslides triggered by previous $M_{j}=7-8$ earthquakes in the same area; Doshida and Uchiyama, 2012), many showed very high mobility, with features typical of flowslide (fluid-like motion of granular material; Bishop, 1973). The fluidized, rapid, long-travel movement of these landslides attracted attention of geotechnical researchers and engineering geologists, because the landslides were scattered in different areas, experienced little preceding precipitation, and displayed no evidence of occurrence beneath the groundwater table. Understanding the initiation and movement mechanisms of these landslides is of great importance to the mitigation of future coseismic geohazards. After the earthquake, we undertook a reconnaissance field examination of the landslides, and investigated seven of them in detail. Here we describe two landslides that occurred in the south part of Fukushima Prefecture and one in Tochigi Prefecture, and discuss their possible initiation and movement mechanisms. By monitoring a landslide area during frequent aftershocks, we could estimate the seismic response of the landslide area during the main shock which triggered the slope instability. Through geotechnical tests on the shear behavior of the landslide materials for different moisture 


\section{Study area}

There were many landslides that occurred in southern Fukushima Prefecture and northern Tochigi Prefecture. As samples of catastrophic landsides, we present data from two landslides (Hanokidaira and Shirasawa) from Shirakawa City, and one occurring in the Oshino area (Fig. 1). Fig. 2 presents a geologic map of the study area, which was based on the 1:200,000 Seamless Digital Geological Map of Japan (Geological Survey of Japan, 2003). This area mainly consists of Mesozoic granite, Paleozoic and Mesozoic sedimentary/ metamorphic rocks, Neogene volcanic rocks and sedimentary rocks, and Quaternary fluvial deposits. All these three landslides occurred in Pleistocene tephra and highly weathered welded tuff in hilly areas in the eastern part of the Ōu Mountains. In the strata of the landslide areas, 12 layers of tephra resulting from eruptions of Nasu Volcano at different times are recognized (Suzuki, 1992). In the following sections, geological details of each landslide are introduced.

Fig. 3 shows the topography of the areas with the Hanokidaira (Fig. 3a), Shirasawa (Fig. 3b), and Oshino (Fig. 3c) landslides. Fig.3a was based on the urban plan map (1/2500) of Shirakawa City, Fukushima Prefecture, while Figs. 3b and 3c were taken from the digital maps of the Geospatial Information Authority of Japan, because the urban plan maps in the scale of 1/2500 for these landslide areas are not available. The prefailure slope of each landslide was steep, and recent fluvial erosion cut and steepened the slope toe (Chigira, 2011).

\section{Methods}

We measured their after-event topography using a laser rangefinder (TruPulse $360^{\circ} \mathrm{B}$ with a resolution of $0.1 \mathrm{~m})$. We also used images from Google Earth to examine the topography of these landslides both before and after the earthquake.

We used a portable seismometer (Character frequency: 1.9-2.1 Hz; Measurable amplitude of vibration: \pm 2 mm; Sensitivity coefficient: $0.8 \mathrm{v}$ kine $^{-1}$ ) to monitor earthquake aftershocks at the Hanokidaira landslide. This seismometer has been developed for dense seismic observation, and has an extremely low power consumption $(<$ 
$710.08 \mathrm{~W})$. It records seismic movement continuously for six months using eight dry-cell batteries, at a sampling rate of $250 \mathrm{~Hz}$ archiving one file per minute. We monitored aftershocks at the site during April 11-29, 2011 and obtained many records.

We employed a series of intelligent ring-shear apparatuses developed at the Disaster Prevention Research Institute, Kyoto University (Sassa et al., 2004), to examine the static and cyclic shear behaviors of samples that were taken from near the sliding surfaces of the landslides. These samples were fully saturated or kept at their natural moisture content during the shear tests, and were sheared under undrained conditions.

\section{Results}

\subsection{Features of fluidized landslides}

\subsubsection{Hanokidaira landslide}

The Hanokidaira landslide (Fig. 4a) originated on a southeast-facing slope of a hill located about $1 \mathrm{~km}$ north of JR Shirakawa Station in Shirakawa City. Thirteen people were killed and 10 houses were destroyed by the debris of the landslide. A small portion of the displaced material spilled into a golf driving range, forming a thin deposit.

Stratigraphically from bottom to top, the slope consists of a basal deeply weathered welded tuff, a palaeosol, weathered pumice and scoria partly with palaeosols, and forest soil. The bedded texture is approximately parallel to the slope surface. The primary palaeosol, which overlies the welded tuff, outcropped, and had striations on its surface (Fig. 4b). We dug into the deposits on the golf driving range and found that grass was flattened and buried by the displaced materials, but not cut or displaced from its original place (Fig. 4c). Above the grass was a displaced $\sim 10 \mathrm{~cm}$ thick palaeosol layer overlain by loose pumice. Many trees had stood almost vertically while being transported. There were muddy striae on the left flank of the landslide (Fig. 4d) and also splashes of mud on the high position above the sliding surface (Fig. 4e), indicating that the displaced mass experienced slide at first and then liquefaction, and the liquefied materials (mud) were splashed 

point in the local landscape (PV-T in Fig. 4g). The most prominent palaeosol in the sequence is developed on developed on the weathered welded tuff.

during downslope movement. Therefore, the movement of this landslide can be classified as earth slide-flow, according to Cruden and Varnes (1996).

Using the above-mentioned laser rangefinder, we surveyed the landslide area to prepare a longitudinal section (Fig. 4f). The main part of the displaced materials spread into a residential area at the foot of the hill, exhibiting substantial fluid-like flow. The apparent mobilized friction angle of the slide was about $9.6^{\circ}$, measured from point I to I' in Fig. 4a. According to the measured topography, we estimated that the volume of the displaced material was about $100,000 \mathrm{~m}^{3}$, with a horizontal travel distance of about $290 \mathrm{~m}$ and a total relief of about $50 \mathrm{~m}$.

No standing ground water or groundwater seepage was found in the landslide source area. However, local residents told us that there was a continuous spring at the toe part of the slope. Therefore, we inferred that standing ground water existed in the slope before the occurrence of the landslide. Due to stabilization countermeasures, the debris on the lower part of the slope, near point $\mathrm{T}$ in Fig. 4a, has been removed and the slope continues to yield water from small springs (observation in July 2012).

At the Hanokidaira landslide source area, tephra layers exposed during excavation for stabilization. The existence of palaeo-valley had been identified (Fig. 4g). The upper surface of the welded tuff (and the palaeosol) indicates a substantially dissected hilly area with a palaeo-valley aligned approximately east-west and sloping to the east (PV-M in Fig. 4g). The palaeo-valley had a tributary (side valley) sloping up towards the present highest this hilly palaeo-surface, which was subsequently mantled and largely buried by thick layers of air-fall volcanic ash. Through erosional reworking of the tephra during the long interval during which all of the layers were deposited, the thickness of the ash pile along the axis of the palaeo-valley has become greater than that on the flanks of the palaeo-valley. The landslide has substantially cleaned out the tephra down to the palaeosol 


\subsubsection{Shirasawa landslide}

The Shirasawa landslide (Fig. 5) is located approximately $4 \mathrm{~km}$ northeast of the Hanokidaira landslide. It originated from a gully head. Like the Hanokidaira landslide, the soil layers in the source area, from the bottom to the ground surface, are a palaeosol, pumice, and weathered volcanic ash with pumice. The bedded texture approximately parallels to the slope surface. The displaced materials slid from the source area above the palaeosol (Fig. 5b), and the left flank was also imprinted by muddy striae and splashes of mud on a high position above the sliding surface (Fig. 5c). Therefore, the movement can be classified as earth slide-flow like the Hanokidaira landslide. The landslide began on a $13^{\circ}$ slope, slid onto a slope of $46^{\circ}$, then turned south and travelled $230 \mathrm{~m}$ along the valley. The total flow length of the slide was $331 \mathrm{~m}$, with a relief of $70 \mathrm{~m}$, giving an apparent mobilized friction angle of $11.9^{\circ}$. The source area was $95 \mathrm{~m}$ long, $30 \mathrm{~m}$ wide and $3 \mathrm{~m}$ thick on average, giving a landslide volume of about $9000 \mathrm{~m}^{3}$. This landslide occurred in a non-residential area and no casualties or injuries were reported.

\subsubsection{Oshino landslide}

The Oshino landslide (Fig. 6a) is located $45 \mathrm{~km}$ south of Shirakawa City. The landslide originated on a northeast- to north-facing slope, below which are terraced paddy fields. The source area is $45 \mathrm{~m}$ long, $55 \mathrm{~m}$ wide and $4 \mathrm{~m}$ thick on average; therefore the landslide volume was approximately $10,000 \mathrm{~m}^{3}$. The displaced materials traveled about $100 \mathrm{~m}$ across a rice paddy, and then descended a $10 \mathrm{~m}$ steep step and continued for further $65 \mathrm{~m}$ across a lower rice paddy (Fig. 6d). The apparent mobilized friction angle of this landslide was $9.5^{\circ}$. The deposits had a thickness of about $3 \mathrm{~m}$ in both paddies. Many trees were standing vertically on the landslide toe.

We dug a pit at the toe and found that the rice paddy soil had been barely disturbed.

The soil layers of the source area were a palaeosol, weathered volcanic ash, and pumice respectively from the base of the sliding surface to the top. Fig. $6 \mathrm{~b}$ presents the outcropped sliding surface with palaeosol 
143 underlain. The bedded texture approximately parallels to the slope surface. On the left flank, muddy striae and

144 splashes of mud on the high position above the sliding surface were also observed (Fig. 6c), indicating that this

145 landslide can be classified as earth slide-flow according to the movement of displaced mass. A witness reported

146 that the sliding occurred and stopped in some seconds during the strong seismic motion.

\subsection{Seismic motion}

City: a Kyoshin Network (K-NET Shirakawa) station of the National Research Institute for Earth Science and presented in Fig. 7a-f, respectively. At both stations, the vertical component of motion was the smallest, and N-S of 1295.2 gal, while the JMA station recorded a maximum of 371.5gal, about one-third of the former. The K-NET station is about $2.8 \mathrm{~km}$ southwest of the Hanokidaira landslide, while the JMA station is about $800 \mathrm{~m}$ south. Therefore, the landslide may have experienced a similar level of a seismic response as that at the JMA station during the main shock. However, seismic responses of a site depend greatly on the local characteristics of soil/rock layers and topography. To better understand the seismic motion of the Hanokidaira area, we installed a

160 seismometer close to the top of the landslide area on April 11, 2011 to record aftershocks and estimated the

161 seismic response during the main shock (Fig. 7g-i) by means of the site-effect substitution method (Hata et al.,

162 2011, 2012). The estimated seismic wave had a peak acceleration of about 907 gal in an N-S direction and 778

163 gal in an E-W direction, about 2.4 and 2.3 times greater than the records from the JMA station respectively.

164 Although the estimated vertical acceleration had a smaller peak value of 463 gal, this value is about 3.4 times

165 greater than that recorded at the JMA station, indicating that the Hanokidaira landslide area had a stronger site 
166 effect on the vertical motion. From Fig. 7g-i, we infer that the peak seismic motion on the slope at Hanokidaira

167 was greater than $1 \mathrm{~g}$, and triggered the failure during the main shock.

\subsubsection{Setup of shear test}

Field surveys revealed that all these landslides had a palaeosol as their basal layer, and all the materials above this layer had been displaced. This suggests that the boundary between the palaeosol layer and the overlying pumice layer played a key role in the initiation and movement of the landslides, and the shear failure

173 formed a sliding surface in both soil layers. Although our field surveys failed to find standing water, i.e., the soil layers might not have been in a fully saturated state, we found that the field moisture content of these soil layers was very high. Also the landslides were all triggered on slopes with small valleys below where ground water tends to converge. We infer that the soil layers near the sliding surface had a very high moisture content or been nearly saturated, and hence liquefaction led to the high mobility of these landslides. (S2) in the source area of each landslide for geotechnical tests. In July 2012, we also took intact samples from the palaeosol layer of the Hanokidaira landslide exposed during stabilization work (S1' in Fig. 4). Two blocks

181 (about $40 \times 40 \times 30 \mathrm{~cm}$ for each) were taken and transported in plastic bags to keep moisture content. Hanokidaira landslide to examine the shear strength of S1 in intact state and also to examine the possible difference between the intact and remolded samples. We also performed undrained shear tests on the remolded 
188 approximately $2.70 \mathrm{~g} \mathrm{~cm}^{-3}$, dry density of $0.48-0.66 \mathrm{~g} \mathrm{~cm}^{-3}$, natural moisture content of 94-160\% and void ratio

189 of 3.10-4.18, while sample S2 had a specific gravity of $2.68 \mathrm{~g} \mathrm{~cm}^{-3}$, dry density of $0.51-0.64 \mathrm{~g} \mathrm{~cm}^{-3}$, natural

190 moisture content of $94-151 \%$, and void ratio of 3.25-4.25. The intact blocks of S1 had a natural moisture

191 content of $114 \%$ and dry density of $0.636 \mathrm{~g} \mathrm{~cm}^{-3}$.

Because the tests were carried out to examine the shear behavior of the soil in the source area, test conditions were designed to represent a soil element on the sliding surface overlain by an $8 \mathrm{~m}$ thick soil (measured vertically) for the Hanokidaira landslide. The normal and shear stresses on the sliding surface were calculated using a slope angle of $16^{\circ}$ (Fig. 4f), and a unit weight of $11.4 \mathrm{kN} \mathrm{m}^{-3}$, which was calculated from the measured in situ density of the sample, assuming that no groundwater table existed in the slide. Thus, the estimated normal stress $\left(\sigma_{\mathrm{i}}\right)$ was $84 \mathrm{kPa}$ and shear stress $\left(\tau_{\mathrm{i}}\right)$ was $24 \mathrm{kPa}$. conditions following the standard of ASTM D3080. The shear box, assembled with the top and bottom halves of the box screwed, has a size of $10 \times 10 \times 10 \mathrm{~cm}$. The remolded samples were prepared to be approximately the same initial dry density as the intact one. We sheared the sample at natural moisture content and also at fully saturated state. For saturated tests, we put the shear box with sample into distilled water for 4 days to ensure full saturation.

We performed undrained ring shear tests on saturated samples following these steps: (1) putting remodeled

205 S1, directly taken from the in-tack blocks in natural water content without any dry process, or air dried S2 into 206 the shear box; (2) saturating the samples using $\mathrm{CO}_{2}$ and de-aired water; (3) normally consolidating the sample under a given stress state; (4) undrained shearing the sample by applying cyclic loadings or increasing only shear 208 stress (static shearing). For tests on samples with the natural moisture content, we put the remolded natural 209 samples into the shear box and then went through steps (3) and (4). More detailed procedures for performing undrained shear tests in a ring shear apparatus are described by Sassa et al (2003). 
We also performed undrained shear tests on fully saturated air-dried or oven-dried samples of S1 to

212 examine the possible effect of drying process on its undrained shear behavior. As pointed out by Chigira et al

213 (2012), the dominant clay mineral in the palaeosol of the studied landslides is halloysite, which is normally

214 formed by hydrothermal alteration of volcanic rocks (Kerr, 1952); while air or oven drying would result in the

215 dehydration of interlayer water of halloysite (Wesley, 1973, 1977; Okada and Ossaka, 1983). Nevertheless,

216 detailed examination on the possible effects of drying process on palaeosol properties is beyond the focus of this study; here we only present the results of tests on those samples with natural moisture contents.

\subsubsection{Results of direct shear box tests on samples $S 1$}

We performed direct shear box tests under differing normal stress levels (84, 64 and $41 \mathrm{kPa}$, respectively).

The intact samples were kept at natural moisture contents or fully saturated, while the remolded samples were kept at their natural moisture contents. The representative failure envelopes from these tests are shown in Fig. 8.

The intact sample at natural moisture content presented an angle of shearing resistance of $\varphi^{\prime}=27^{\circ}$ with an apparent cohesion, $c$, of $22 \mathrm{kPa}$ (Fig. 8). These strength parameters varied greatly when the sample was remolded, showing $\varphi^{\prime}=14^{\circ}$ and $c=26 \mathrm{kPa}$. Fully saturated intact sample behaved slight change in the strength high (the saturation degree was $94.3 \%$ ). 


\subsubsection{Results of cyclic shearing at natural moisture contents}

Undrained cyclic shear tests were conducted on both samples at natural moisture contents (114\% and 140\% for S1 and S2, respectively). After being placed in the shear box and normally consolidated, the samples were subjected to a cyclic shear stress, with an amplitude of $24 \mathrm{kPa}$ (i.e., $24 \mathrm{kPa}$ cyclic load superimposed onto the 24 $\mathrm{kPa}$ gravitational shear load) and a frequency of $0.5 \mathrm{~Hz}$ under undrained conditions. We used this low-frequency for better monitoring the response of pore-water pressure that might be generated during the shearing. Fig. 9 presents the results as time series data for both samples. In these tests, normal stress was kept constant. However, the cyclic shear stress was not faithfully applied by the control system, probably because this ring shear apparatus was designed for high stress level (maximal normal stress: $2 \mathrm{MPa}$ ), and the cyclic shear stress of 24 $\mathrm{kPa}$ is relatively too small. Nevertheless, in both tests, shear failure was triggered due to the introduction of cyclic shear loading, and continued even after the cyclic shear loading ceased. With continuing cyclic shearing, the shear resistance became smaller than the initial shear stress. This enabled continuing shear failure and shear resistance lowered further to approximately zero.

The monitored pore-water pressure was small, likely due to the air left inside the samples and also inside the pore-water pressure measuring system. The highly compressible air would cause a delayed reaction to the change in pore-water pressure. The low permeability of the sample (clayey soil) may also delay the response of the pore-water pressure monitoring system, because the excess pore water pressure was generated within the shear zone, while the pore-water pressure measuring system was installed near but outside of the shear zone (Wang et al, 2007). Disturbed sample S2 has a permeability of approximate $2.9 \times 10^{-2} \mathrm{~cm} \mathrm{~s}^{-1}$ at a dry density of about $0.51 \mathrm{~g} \mathrm{~cm}^{-3}$, while sample $\mathrm{S} 1$ has a permeability of about $1.3 \times 10^{-5} \mathrm{~cm} \mathrm{~s}^{-1}$ at a dry density of about $0.64 \mathrm{~g}$ $\mathrm{cm}^{-3}$, smaller than that of S2. This may be the reason why the monitored excess pore water pressure in Fig. 9a was smaller than that in Fig. 9b. However, we inferred that the excess pore-water pressure built up within the shear zone had reached to a value approximately equal to the total normal stress, such that the shear resistance lowered approximately to zero after 40 seconds in both tests. 
Although additional shear stress of about $24 \mathrm{kPa}$ had been applied to the initial shear stress once (Fig. 9a),

the applied cyclic shear stress was smaller than $24 \mathrm{kPa}$ in general, resulting in changes in the number of cycles necessary for the initiation of shear failure, but has no effect on the post failure shear behavior (Wang, 2000). Therefore, considering the strong motion and long duration of the main shock of the earthquake and the inferred degree of saturation, we concluded that liquefaction occurred within the soil layers near the sliding surface.

\subsubsection{Results of static shearing at natural moisture content}

Considering that the side wall of the landslide mass would suffer from static shearing after the landsliding with a moisture content of $140 \%$ was normally consolidated under the normal stress of $84 \mathrm{kPa}$ and shear stress of $24 \mathrm{kpa}$, and then sheared by increasing shear stress monotonically under undrained condition. Fig. 10 shows an example of the results of this test. With increasing shear stress, excess pore water pressure was built up gradually. After shear failure occurred, shear resistance gradually lowered to a very small value close to zero. Vertical displacement (positive with sample consolidation) also occurred as shearing progressed.

After the test, we opened the drainage system, and found water being expelled from the shear box. Therefore, even though the sample was not fully saturated, the abundant water in the sample allowed generation of high pore-water pressure after shear failure was triggered.

\subsubsection{Shear rate dependency of the palaeosol}

Once shear failure occurred, we expected that the displaced landslide material might not accelerate at a constant rate due to strength change with shear rate. To examine this effect, we sheared both samples at different

281 shear rates. The samples were first saturated, and consolidated under a total normal stress of about $200 \mathrm{kPa}$. This 
284 shear-speed-controlled method. We performed multistage test, which has been found to produce results similar

285 to the test of individual samples (Bromhead, 1992; Tika et al., 1996; Tiwari and Marui, 2004; Suzuki et al., 286 2004; Wang et al., 2010). After the measurement of residual shear strength at a given shear rate, we repeatedly 287 changed the shear rate and then measured the residual shear strength at this differing shear rate. Through this 288 method, the residual shear strengths at different shear rates were measured (Fig. 11). We found that the effect of 289 shear rate on the residual shear strength was significant for the palaeosol sample, and that the shear strength of sample S2 was less affected by the shear rate. The residual shear strength was greater than $150 \mathrm{kPa}$ when the 291 shear rate was smaller than $0.6 \mathrm{~mm} \mathrm{~s}^{-1}$, but was smaller than $50 \mathrm{kPa}$ when the shear rate was greater than $1 \mathrm{~mm}$ $292 \mathrm{~s}^{-1}$. Although the reason for this sharp decrease in shear resistance with shear rate is unclear, it can be concluded 293 that the shear resistance became very small when the displaced material moved faster.

\section{Discussion}

To analyze landside mobility, a parameter of travel angle $\left(\varphi_{a}\right)$, sometimes called apparent friction angle, has been widely used (Scheidegger, 1973; Cruden and Varnes, 1996). The parameter is defined as $\tan \varphi_{a}=H / L$, where $H$ is the landslide height (the difference in elevation between the crown and the tip of the landslide), and $L$ is the horizontal distance of the landslide from the toe to the head scarp. Small values of $\varphi_{a}$ mean high mobility 300 and the value tends to decrease with increasing volume (Scheidegger, 1973; Voight et al., 1983; Legros, 2001;

301 Crosta et al., 2005). In addition, landslides involving volcanic materials usually have higher mobility (Hayashi 302 and Self, 1992; Legros, 2001). Recently studies showed that some small, rapid, fluidized landslides due to 303 rainfall (Wang, 2000) or earthquakes (Crosta et al., 2005) have $\varphi_{a}$ of about $10^{\circ}$. The landslides we investigated 304 (Figs. 4 to 6) also had similar $\varphi_{a}$ values of $9.6^{\circ}$ (Hanokidaira), $11.9^{\circ}$ (Shirasawa), $11.8^{\circ}$ (Oshino), and 9.5 (Slide 305 I in Fig. 6), showing high mobility, although most of the landslide materials were unsaturated.

306 Iverson et al. (1997) pointed out that liquefaction plays a key role in the formation of fluidized landslides. In 307 the case of coseismic landslides, the slope instability may result from 1) coseismic force that may make 
308 downslope shear stress greater than shear strength, and (2) buildup of excess pore-water pressure within fully or

309 partially saturated soil layers that may lower the shear strength. In the case of fluidized coseismic landslides, if

310 the excess pore-water pressure increases and the effective normal stress decreases, shear failure may occur, and

311 excess pore-water pressure may further increase with the progress of the failure. As shown in Fig. 8, sample S2

312 has lower shear resistance than sample S1, indicating that if coseismic force is great enough, the first shear

313 failure occurs within the palaeosol layer. During the subsequent downslope movement of the displaced material,

314 the overlaying soil layer of pumice and scoria experiences further vibration and static shearing, leading to

315 liquefaction. This may be the reason why the deposited landslide materials mainly consist of fluidized pumice

316 with little palaeosol. Therefore, for the risk analysis of fluidized landslides, it is necessary to better understand

317 both the coseismic shear and static shear behaviors of soil layers within a slope.

318 Numerous tests have been performed on fully saturated sands to examine their liquefaction behavior (c.f.,

319 Seed, 1966; Finn, 1981; Ishihara, 1993). However, recent studies reveal that even under unsaturated conditions,

320 sand with a highly compressible soil may liquefy (Kazama et al., 2006; Unno et al, 2006, 2008). The undrained

321 shear tests on samples S1 and S2 (Figs. 9 and 10) indicate that full liquefaction can occur in both samples after

322 shear failure although they are only partially saturated.

323 The amplification of seismic movement due to slope topography has been recognized (Davis and West,

324 1973; Ashford et al., 1997; Nishimura and Morii, 1984; Kurita et al., 2003; Buech et al., 2010). Although greater

325 amplification normally occurs on the crest of a slope, the vertical motion of a bedrock-dominated slope is rarely

326 affected by topography (Kurita et al., 2003). Recent studies reveal that the seismic motion especially in the

327 vertical direction is also dependent on the degree of soil saturation resulting in non-linear soil response (Yang

328 and Sato, 2000; Tobita et al, 2010). The estimated seismic motion shown in Fig. 7g-i was based on a practical

329 estimation method of strong ground motion (called "site-effect substitution method") that was proposed by Hata

330 et al (2011). This method uses the records of aftershocks both at the site of interest and at a nearby permanent

331 strong motion observation station, and the record during the main shock at the observation station. Because this 
method takes account of not only the difference of site amplification factors, but also the difference of site phase

333 effects between the site of interest and the observation station, it can estimate time histories of strong ground

334 motion at the site of interest with high accuracy. However, this method does not consider the effect of strong

335 nonlinearity of shallow soft soil, which can greatly change the ground-motion amplification of shallow soil

336 layers (Field, et al., 1997; Beresnev et al., 1998). Therefore, the estimated seismic motion might be

337 representative of the response of engineering bedrock, as considered in the field of earthquake engineering,

338 rather than of shallow soil. The engineering bedrock in earthquake engineering is normally determined by the

339 S-wave velocity (Vs) of the bedrock, approximately $300-700 \mathrm{~m} \mathrm{~s}^{-1}$. The seismic motion of surficial soil with

340 smaller $V$ s tends to be greater. Further, soil layers in the source area had high moisture content but were not fully

341 saturated. This state could result in a large amplification of vertical motion. We checked the seismic recordings

342 obtained during the aftershocks and found that the vertical motion on the landslide site could be up to about 9

343 times that recorded by the nearby JMA station, although the estimated vertical motion during the main shock

344 (Fig. 7i) is about 3.4 times that of the JMA records. Although we did not perform further analysis on the possible

345 elastic-plastic earthquake response of the slope, the ground motion of the slope during the main shock may have

346 been much stronger than the estimates in Fig. $7 \mathrm{~g}$-i.

In the analysis of coseismic landsliding, the effect of vertical motion on the instability of slopes has been

348 largely ignored. Nevertheless, recent field monitoring and theoretical analysis have revealed that vertical motion

349 also plays an important role in landslide initiation (Yang, 2007). For the studied landslides, strong vertical

350 motion may have contributed to their initiation through two processes: coseismic shear force and compression

351 (or collapse) of unsaturated soil layers, which build up excess pore-water pressure in unsaturated soils during the

352 earthquake. Although the seismic response of a given site to a given earthquake depends on many factors, the

353 direct seismic observation at a landslide site may provide promising data for better understanding the initiation 


\section{Conclusions}

During the 2011 Tohoku Earthquake off the Pacific coast of Japan, many landslides were triggered in urban residential regions and on natural slopes, killing more than a dozen people and destroying many homes. These landslides were not very large but characterized by high mobility and a long travel distance. Through field movement mechanisms were examined. The conclusions are as follows.

(1) The landslides in pyroclastic fall deposits showed very high mobility, with the occurrence of

363 liquefaction. Valley incision was distinct at the toe of these landslides, indicating that the upper slope of the 364 landslide source area was less stable state before the earthquake.

(2) Although the epicenter was distant, and the motion recorded by a nearby permanent seismic station was not strong, the seismic motion at the Hanokidaira landslide area was very strong due to local site effects.

(3) For each landslide, the sliding surface was along the boundary between a palaeosol developed on generated even when the soil layers are not fully saturated.

(4) The shear resistance of the basal palaeosol markedly decreased with increasing shear rate, indicating

374 that in the case of a shear failure within the palaeosol, the shear resistance of the sliding surface might become materials. 
The seismic recordings of the K-NET operated by the National Research Institute for Earth Science and Disaster

380 Prevention (NIED), Japan, and of the Japan Meteorological Agency, were used in this study. This study was

381 supported by two scientific research grants (No. 21403002 and No. 23310125) from the MEXT, Japan. Prof.

Masahiro Chigira (Kyoto University), Prof. Katsuo Sasahara (Kochi University), Dr. Marui McSaveney (2012 valuable discussion. Mr. Yao Jiang (Kyoto University) is thanked for their help in the laboratory testing. for their valuable comments that substantially improved this paper.

\section{References}

Ashford, S.A., Sitar, N., Lysmer, J., Deng, N., 1997. Topographic Effects on the Seismic Response of Steep Slopes. Bulletin of the Seismological Society of America 87, 701-709.

Beresnev, I.A., Field, E.H., Johnson, P.A., Van Den Abeele, K.E.A., 1998. Magnitude of nonlinear sediment response in Los Angeles basin during the 1994 Northridge, California, earthquake. Bulletin of the Seismological Society of America 88, 1097-1084.

Bishop, A.W., 1973. The stability of tips and spoil heaps. Quarterly Journal of Engineering Geology \& Hydrogeology 6, 335-376.

Bromhead, E.N., 1992. Stability of Slopes (2nd edition). Surrey University Press, London.

Buech, F., Davies, T., Pettinga, J.R., 2010. The Little Red Hill seismic experimental study: Topographic effects on ground motion at a bedrock-dominated mountain edifice. Bulletin of the Seismological Society of America 100, 2219-2229.

Chigira, M., 2011. Survey results of the landslides (in Fukushima and Tochigi prefectures) and earthquake faults (in Fukushima) occurring during the 2011 off the Pacific coast of Tohoku Earthquake. At: http://www.dpri.kyoto-u.ac.jp/web_j/saigai/tohoku2011/jiban_20110426.pdf.

Chigira, M., Nakasuji A., Fujiwara, S., Sakagami, M., 2012. Catastrophic landslides of pyroclastics induced by the 2011 off the Pacific coast of Tohoku Earthquake. In Earthquake-induced landslides (Ugai et al., eds.), Proceedings of the International Symposium on Earthquake-induced Landslides, Kiryu, Japan, 2012. pp.139-147.

Crosta, G.B., Imposimato, S., Roddeman, D., Chiesa, S., Moia, F., 2005. Small fast-moving flow-like landslides in volcanic deposits: The 2001 Las Colinas Landslide (El Salvador). Engineering Geology 79, 185-214.

408 Cruden D.M., Varnes D.J., 1996. Landslide types and processes. In Landslides: Investigation and Mitigation (Turner and Schuster, eds.), National Academy Press, p: 36-71. 
Davis, L.L., West, L.R., 1973. Observed effects of topography on ground motion. Bulletin of the Seismological Society of America 63, 283-298.

Doshida, S., Uchiyama, S., 2012. Features and Distribution of Landslides in the 2011 off the Pacific Coast of Tohoku

Field, E.H., Johnson, P.A., Beresnev, I.A., Zeng Y., 1997. Nonlinear ground-motion amplification by sediments during the 1994 Northridge earthquake. Nature 390, 599-602.

Finn, W.D.L., 1981. Liquefaction potential development since 1976. Proceedings of the International Conference on Recent Advances in Geotechnical Earthquake Engineering and Soil Dynamics, St. Louis, Missouri, 655-681.

Geological Survey of Japan, 2003. Geological map of Japan at scale 1:200 Million (5 $5^{\text {th }}$ version, CD-ROM).

Hata, Y., Nozu, A., Ichii, K., 2011. A practical method to estimate strong ground motions after an earthquake based on site amplification and phase characteristics. Bulletin of the Seismological Society of America 101, 688-700.

Hata, Y., Wang, G., Kamai, T., Suemine, A., Nozu, A., 2012. Seismic waveform estimation at the Hanokidaira landslide induced by the 2011 off the Pacific coast of Tohoku Earthquake based on site effects substitution method. Journal of Japan Landslide Society 49(3), 15-24 (in Japanese with English abstract).

Hayashi, J.N., Self, S., 1992. A comparison of pyroclastic flow and debris avalanche mobility. Journal of Geophysical Research 97, 9063-9071.

Ishihara, K., 1993. Liquefaction and flow failure during earthquakes. Géotechnique 43, 349-451.

Iverson, R.M., Reid, M.E., LaHusen, R.G., 1997. Debris-flow mobilization from landslides. Annual Review of Earth and Planetary Sciences 25, 85-138.

Kazama, M., Takamura, H., Unno, T., Sento, N., Uzuoka, R., 2006. Liquefaction mechanism of unsaturated volcanic sandy soils. JSCE, Journal of Geotechnical Engineering 62, 546-561 (in Japanese).

Kerr, P. F., 1952. Formation and occurrence of clay minerals. Clays and Clay Minerals 1, 19-32

Kurita, T., Annaka, T., Takahashi, S., Shimada, M., Suehiro, T., 2003. Effects of irregular topography on strong ground motion amplification. Transactions of the $17^{\text {th }}$ International Conference on Structural Mechanics in Reactor Technology (SMiRT 17), Prague, August 17-22. Paper \#K03-1.

Nishimura, K., Morii, W., 1984. An observed effects of topography on seismic ground motions. Bulletin of Disaster Prevention Research Institute, Kyoto University, Vol.34, Part 4, No.310, 203-214.

Okada, K., Ossaka, J., 1983. Dehydration mechanism of interlayer water of halloysite. Journal of the Ceramic Association, Japan 91, 329-334 (in Japanese with English abstract)

Sassa K., Wang, G., Fukuoka, H., 2003. Performing undrained shear tests on saturated sands in a new intelligent type of ring

443 Sassa, K., Fukuoka, H., Wang, G., Ishikawa, N., 2004. Undrained dynamic-loading ring-shear apparatus and its application to 444 landslide dynamics. Landslides 1, 1-13.

445 Scheidegger, A.E., 1973. On the prediction of the reach and velocity of catastrophic landslides. Rock Mechanics 5, 231 - 236. 
Seed, H.B., 1966. Landslides during earthquakes due to soil liquefaction. Journal of the Soil Mechanics and Foundations Division, ASCE 94, 1055-1122.

Suzuki, T., 1992. Tephrochronological study on Nasu Volcano. Bulletin of Volcanological Society of Japan (Kazan) 37, 251-263 (in Japanese with English abstract).

Suzuki, M., Kobayashi, K., Yamamoto, T., Matsubara. T., Hukuda. J., 2004. Influence of shear rate on residual strength of clay in ring shear test. Research Report, School of Engineering, Yamaguchi University 55(2), 49-62.

Takeshi, T., 2011. Landslide hazards immediately after the 2011 off the Pacific coast of Tohoku Earthquake and landslides in Shirakawa city, Fukushima. Report on the debriefing session of landslide hazards triggered by the 2011 off the Pacific coast of Tohoku Earthquake, Japan Landslide Society.

Tika, T.E., Vaughan, P.R., Lemos L., 1996. Fast shearing of pre-existing shear zone in soil. Géotechnique 46, 197-233.

Tiwari, B., Marui, H., 2004. Objective oriented multistage ring shear test for shear strength of landslide soil. Journal of Geotechnical and Geoenvironmental Engineering 130, 217-222.

Tobita, T., Iai, S., Iwata, T., 2010. Numerical analysis of near-field asymmetric vertical motion. Bulletin of the Seismological Society of America 100, 1456-1469

Unno, T., Kazama, M., Uzuoka, R., Sento, N., 2006. Change of moisture and suction properties of volcanic sand induced by shaking disturbance. Soils and Foundations 46, 519-528.

Unno, T., Kazama, M., Sento, N., Uzuoka, R., 2008. Liquefaction of unsaturated sand considering the pore air pressure and volume compressibility of the soil particle skeleton. Soils and Foundations 48, 87-99.

Voight, B., Janda, R.J., Glicken, H., Douglass P.M., 1983. Nature and mechanisms of the Mount St. Helens rock-slide avalanche of 18 May 1980. Géotechnique 33, 243-273.

Wang, G., 2000. An experimental study on the mechanism of fluidized landslide - with particular reference to the effect of grain size and fine-particle content on the fluidization behavior of sands. PhD thesis, Kyoto University. 209 pp.

Wang, G., Sassa, K., Fukuoka, H., Tada T., 2007. Experimental study on the shearing behavior of saturated silty soils based on ring shear tests. Journal of Geotechnical and Geoenvironmental Engineering ASCE 133, 319-333.

Wang, G., Suemine, A., Schulz, W.H., 2010. Shear-rate-dependent control on the dynamics of rainfall-triggered landslides, Tokushima Prefecture, Japan. Earth Surface Processes and Landforms 35(4), 407-416.

Wesley, L.D., 1973. Some basic engineering properties of halloysite and allophane clays in Java, Indonesia. Géotechnique $23,471-494$.

Wesley, L.D., 1977. Shear strength properties of halloysite and allophane clays in Java, Indonesia. Géotechnique 27, 125-136.

Yang, J., 2007. On seismic landslide hazard assessment. Géotechnique 57, 707-713.

Yang, J., Sato, T., 2000. Interpretation of seismic vertical amplification observed at an array site. Bulletin of the Seismological Society of America 90, 275-285. 
Captions:

Fig. 1. Locations of the epicenter of the 2011 Tohoku earthquake off the Pacific coast of Japan and the landslides presented in this study (after Google Map). ○: Location of city; $\bullet$ : Location of landslide.

Fig. 2. Geological map of the study area (after Geological Survey of Japan, 2003)

Fig. 3. Topographic maps. (a) Hanokidaira landslide area (based on the planning map of Shirakawa City with a contour interval of $2 \mathrm{~m}$ ); (b) and (c): Shirasawa and Oshino areas, respectively (based on the digital map of Geospatial Information Authority of Japan with a contour interval of $10 \mathrm{~m}$ ).

Fig. 4. Hanokidaira landslide. (a) Oblique view (after Takeshi 2011); (b) view of the left side margin and sliding surface; (c) buried grass on the golf driving range and palaeosol layer above the grass; (d) muddy striae on the left-side margin; (e) splashed mud on left-side margin; (f) longitudinal section along line I-I'; (g) outcropped palaeo-valley in the source area of the Hanokidaira landslide. PV-M: main palaeo-valley; PV-T: tributary of the main palaeo-valley. S1 and S1': Sampling locations for disturbed and intact samples of palaeosol, respectively.

Fig. 5. Shirasawa landslide. (a) Oblique view (after Takeshi 2011); (b) sliding surface and outcropping palaeosol on the source area; (c) Muddy striae and splashed mud on the left side margin.

Fig. 6. Oshino landslide. (a) Oblique view, (b) Outcropped sliding surface and palaeosol; (c) muddy striae and splashed mud on left side of the margin; (d) longitudinal section along I-I'.

Fig. 7. Seismic records and maximum acceleration from the K-NET Shirakawa station (a-c), the JMA Shirakawa-shi Kakunai station (d-f), and the estimated seismic waves in the Hanokidaira area (g-i). EW, NS, UD: seismic motion in the direction of east-west, north-south, and up-down (vertical).

Fig. 8. Drained shear strength and failure envelopes of the intact and remolded sample $\mathrm{S} 1$ at natural moisture content by direct shear box tests. Also showing the failure envelopes of the intact and remolded sample S2 at saturated state obtained by triaxial compression tests.

Fig. 9. Undrained cyclic shear tests on saturated samples $\mathrm{S} 1$ (a) and S2 (b). The dry densities (after consolidation) were 0.70 and $0.51 \mathrm{~g} \mathrm{~cm}^{-3}$ for $\mathrm{S} 1$ and $\mathrm{S} 2$, respectively.

Fig. 10. Undrained shear test on sample S2 (moisture content: 140\%). (a) Time series data of stresses, pressure and shear displacement; (b) vertical displacement (positive indicates sample consolidation). The dry density of the sample after consolidation was $0.55 \mathrm{~g} \mathrm{~cm}^{-3}$.

Fig. 11. Residual shear resistance of saturated $\mathrm{S} 1$ at different shear rates. 
$539 \quad$ Figures

540

541

542

543

544

545

546

547

548

549

550

551

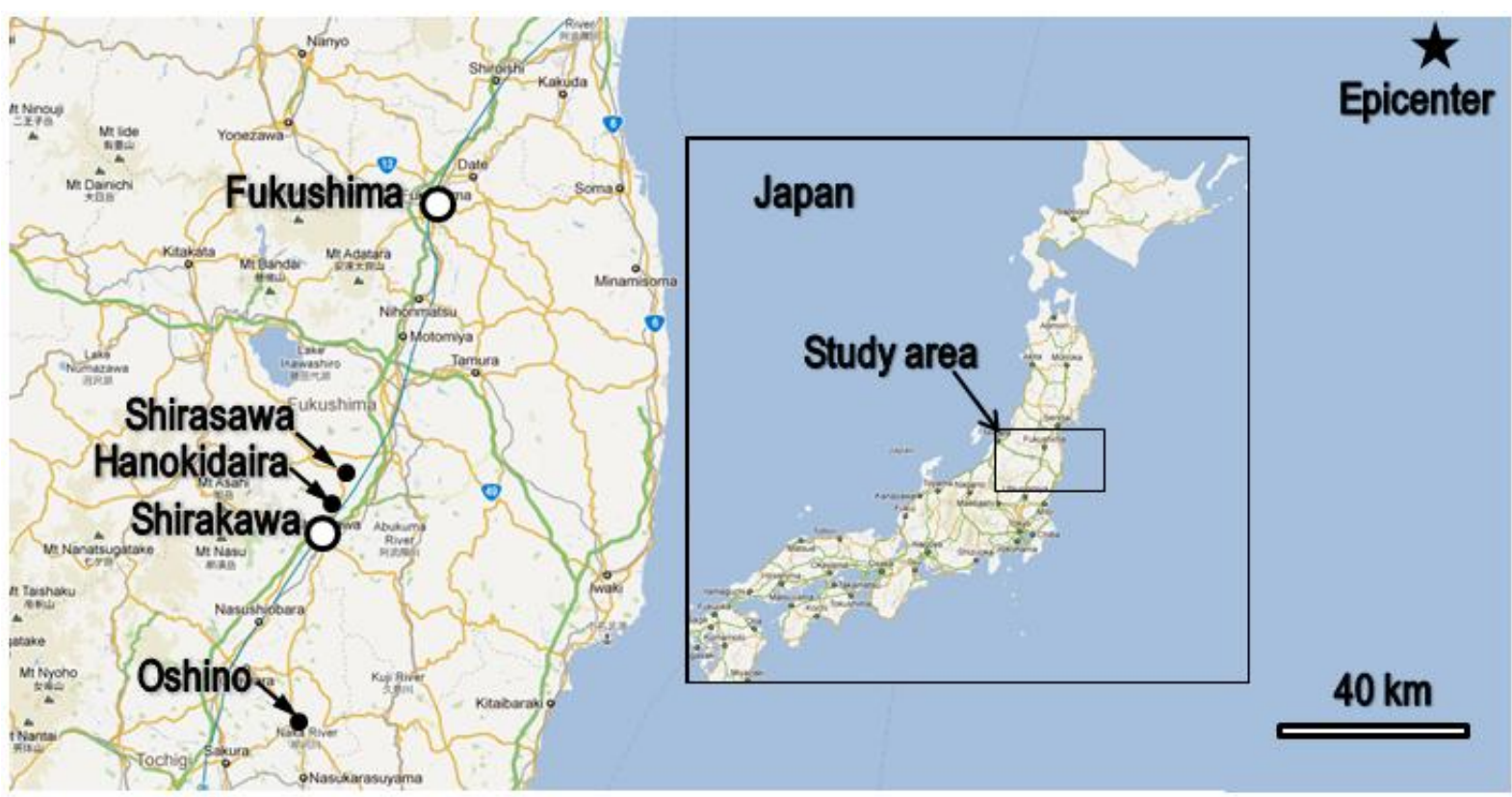

552

Fig. 1 
553

554

555

556

557

558

559

560

561

562

563

564

565

566

567

568

569

570

571

572

573

574

575

576

577

578

579

580

581

582

583

584

585

586

587

588

589

590

591

592

593

594

595

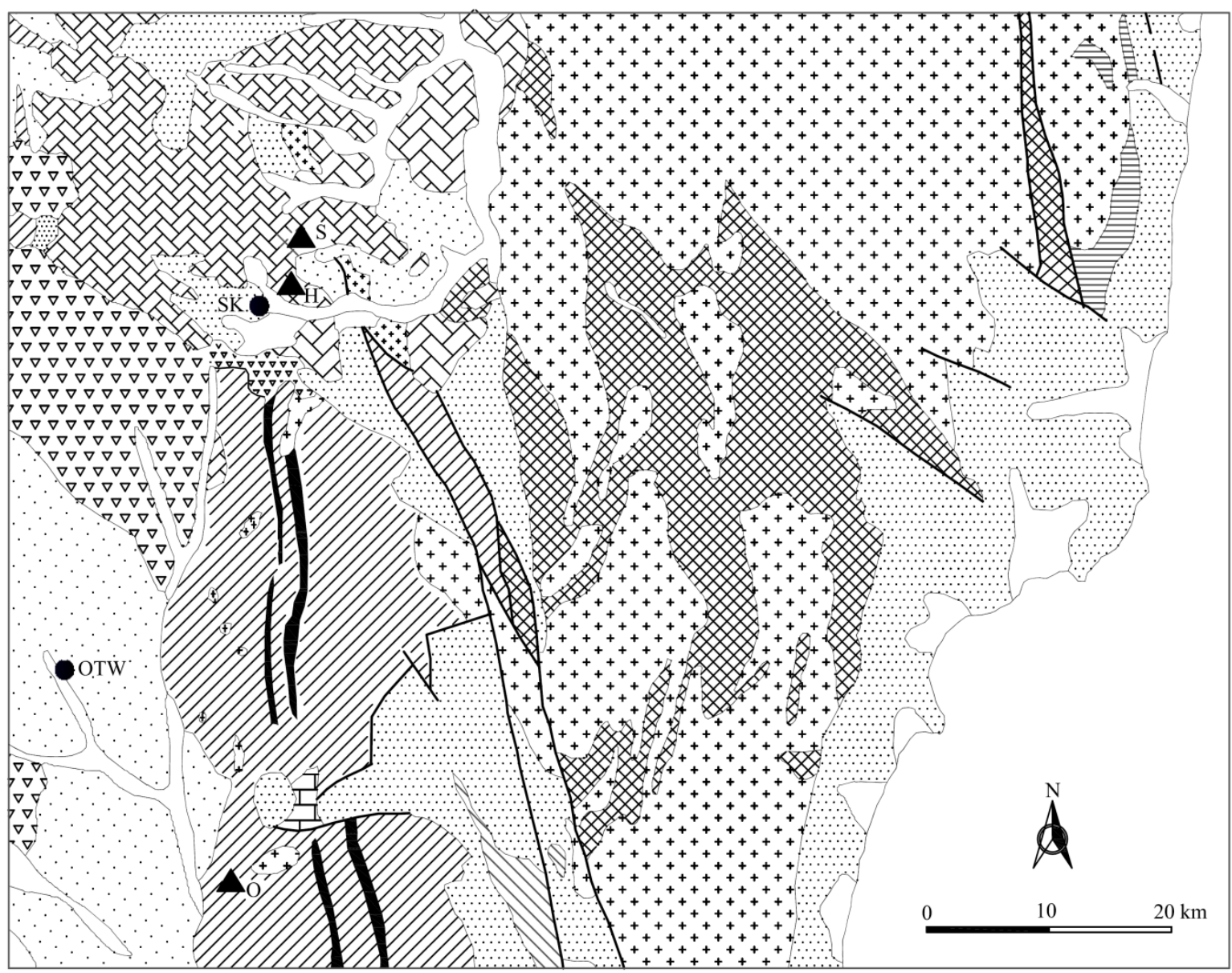

$\square$ Sediments (after Holocene)

$\because \cdots \cdots \cdots$ Sediments (Quaternary)

Pyroclastic flow deposits (Quaternary)

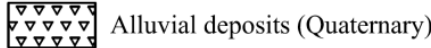

1. Andesitic rocks (Miocene)

Sedimentary rocks (Tertiary)

$+_{++}^{+}$Granitic rocks (Cretaceous)

Chert (Jurassic)

7 Clayslate, Sandstone \& Alternation of strata (Middle Paleozoic)

Sedimentary rocks (Middle Paleozoic) Greenschist, Metamorphic rocks

A: Shirasawa

A: Harokidaira

O: Oshino

SK: Shirakawa

OTW: Otawara 


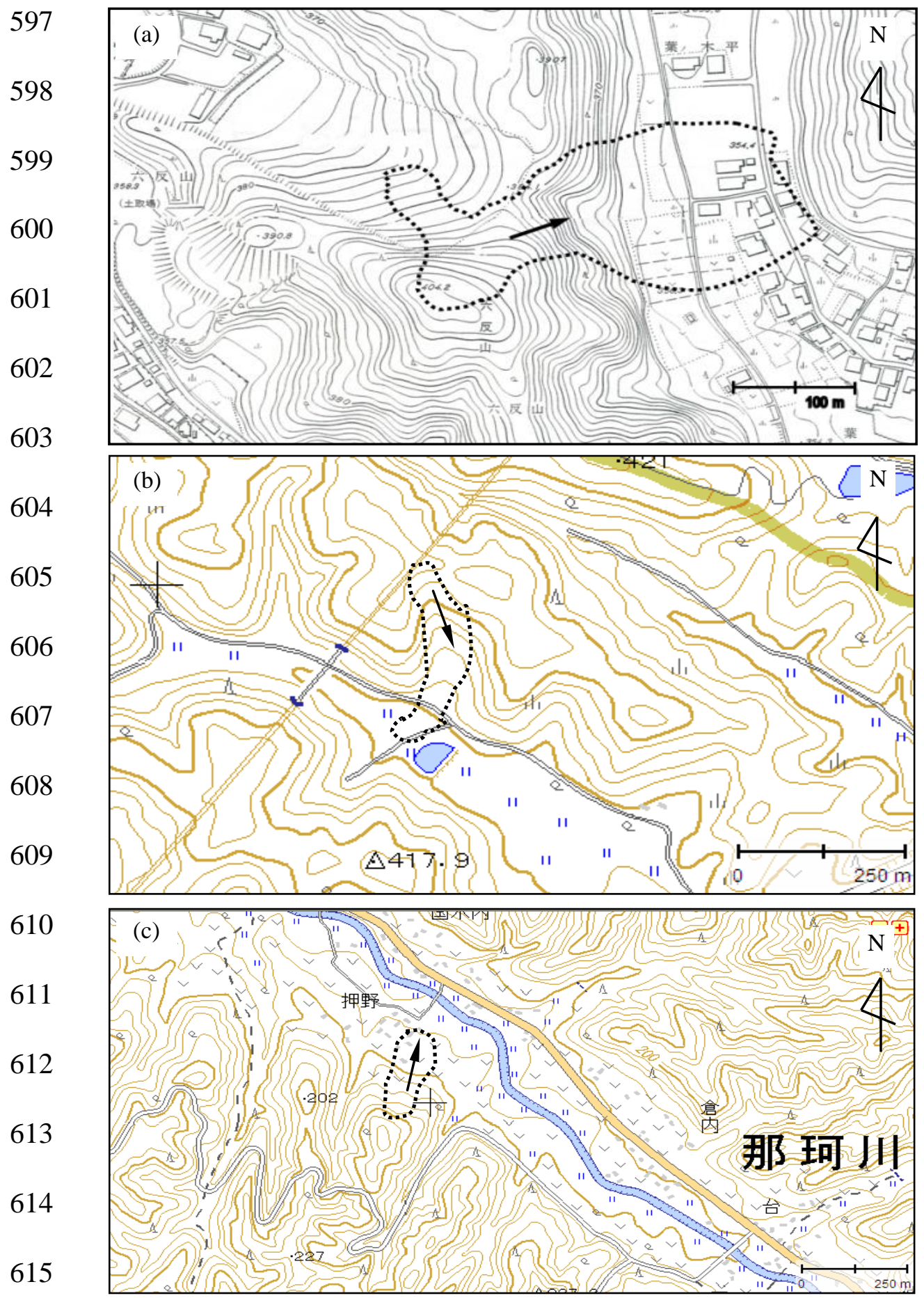

616 Fig. 3.

617

618

619

620

621

622

623

624

625 

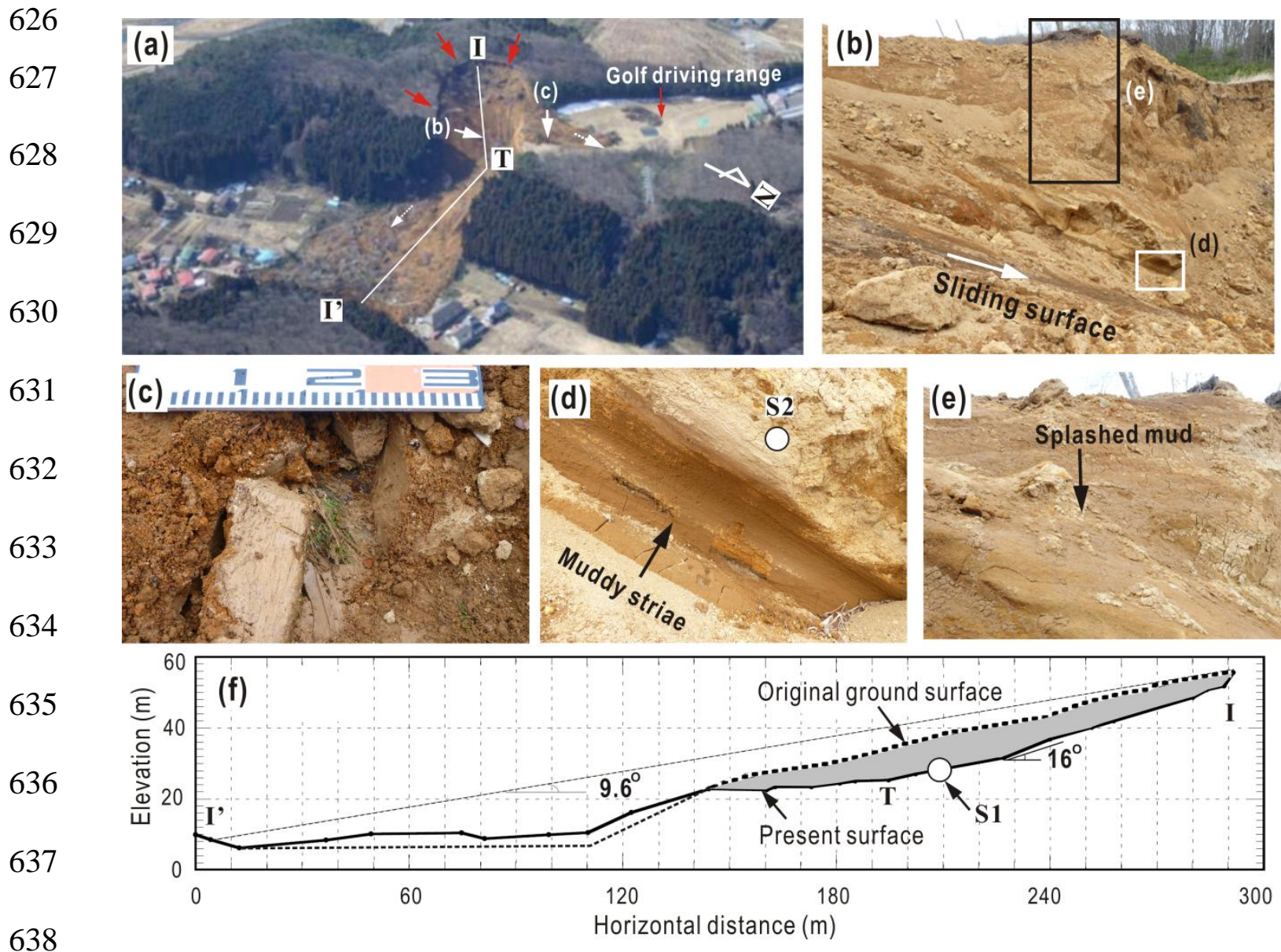

639

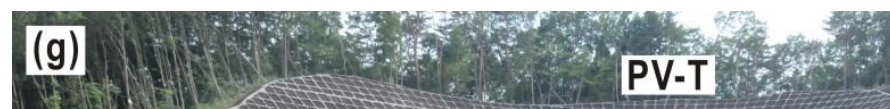

640

641

642

643

644

645 Fig. 4.

646

647

648

649

650

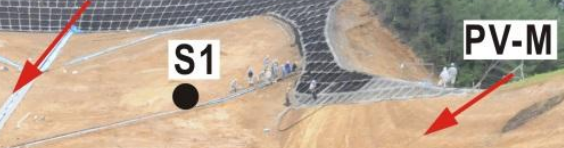

\section{S1'O}

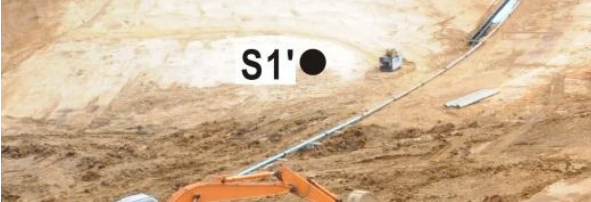




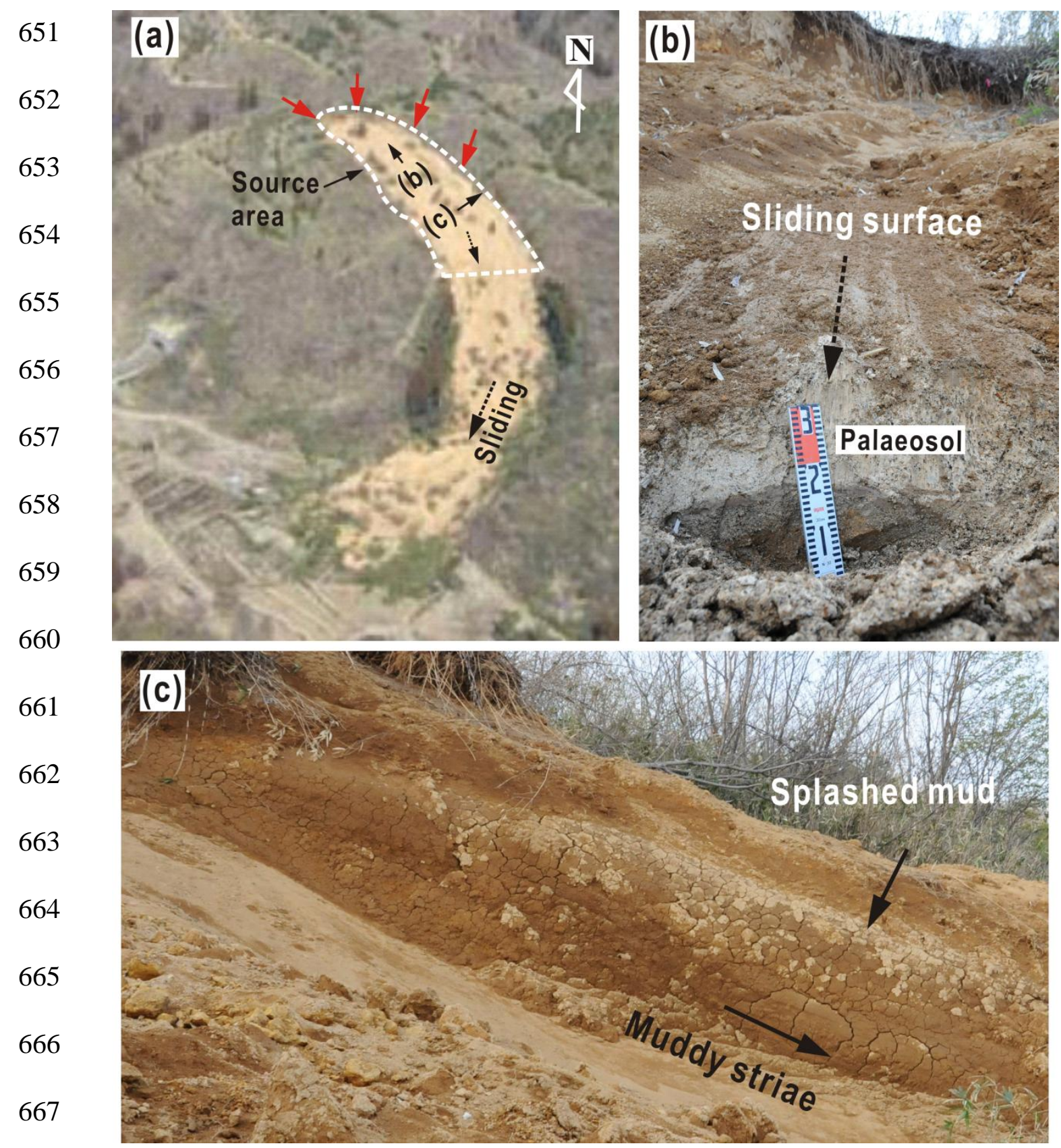

668

669

Fig. 5.

670

671

672

673

674 


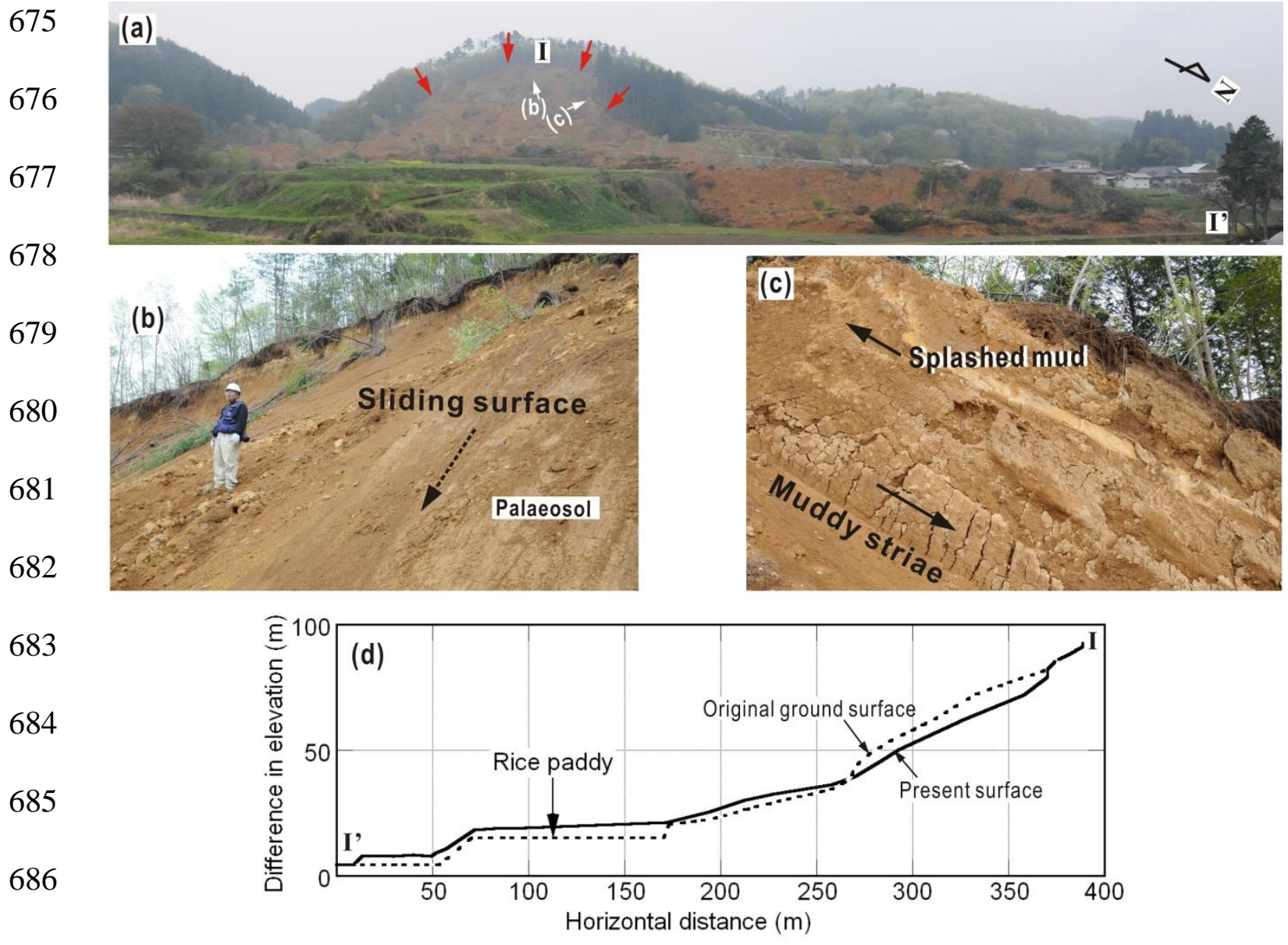

687

688 Fig. 6.

689

690

691

692

693

694

695

696

697

698 


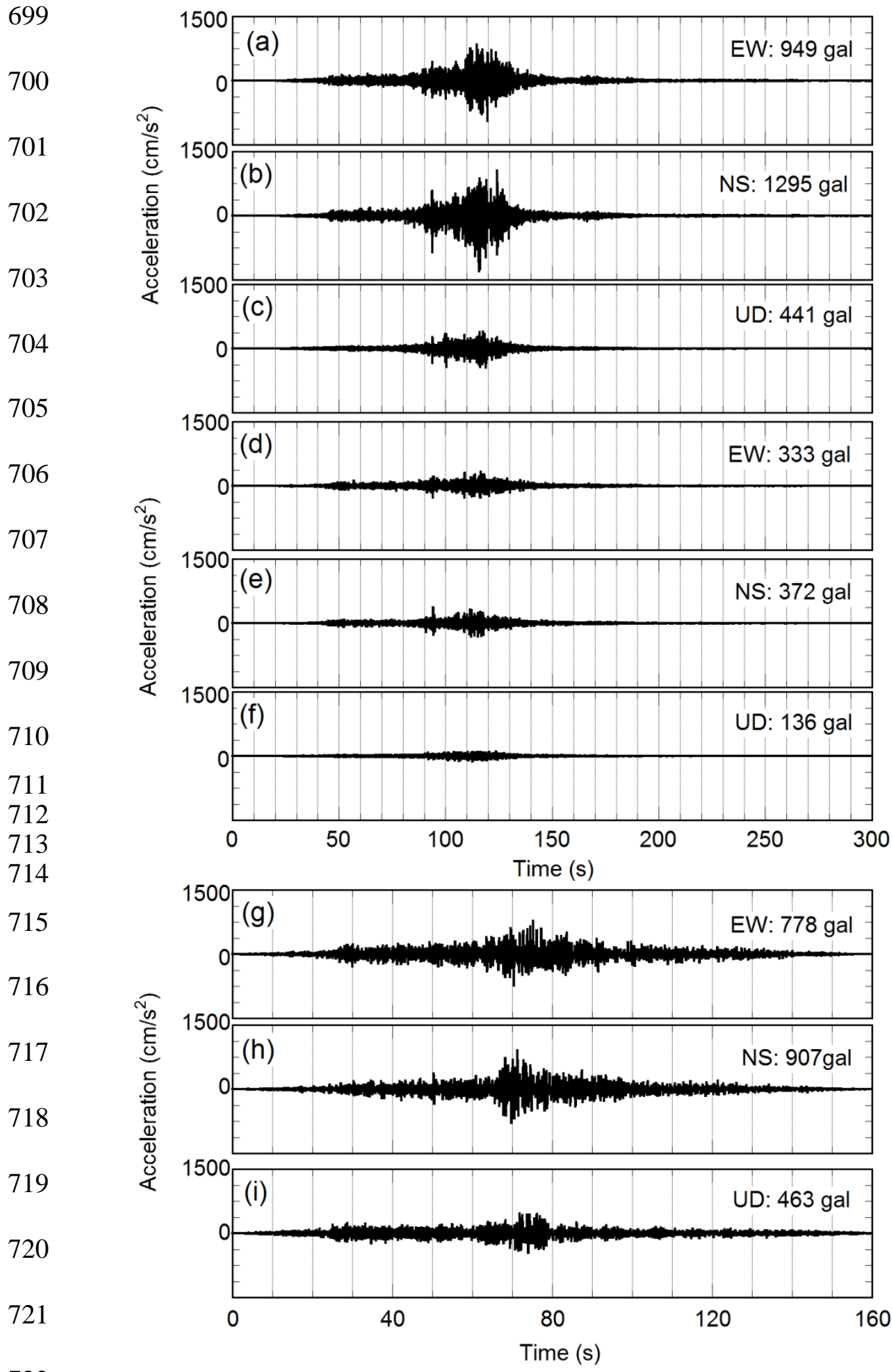

Fig. 7. 


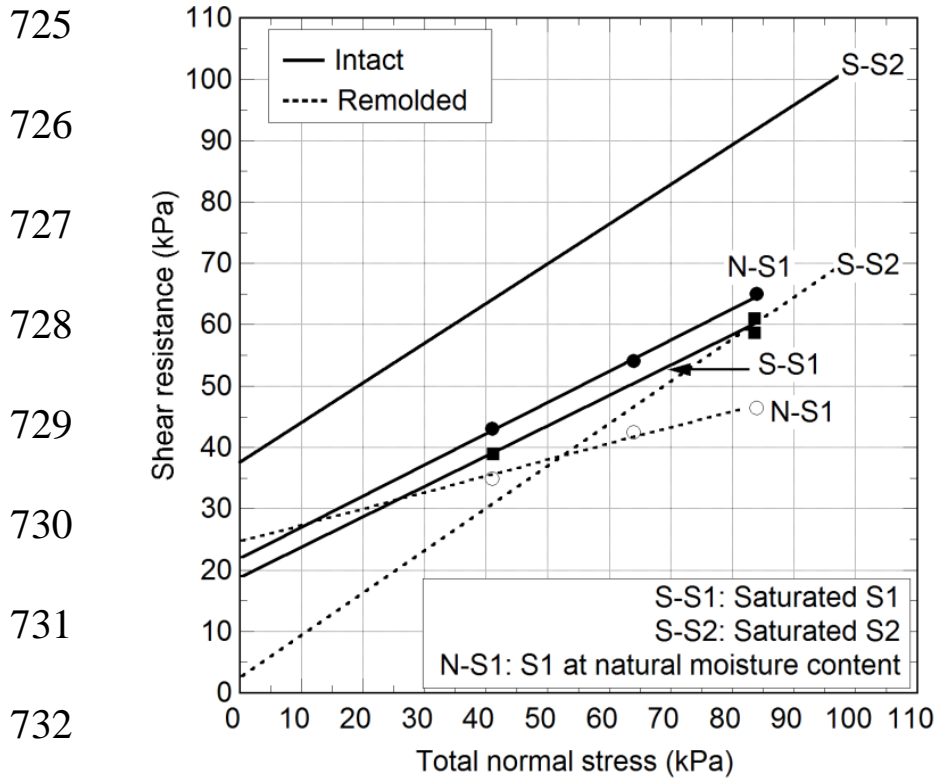

$733 \quad$ Fig. 8

734

735

736

737

738

739

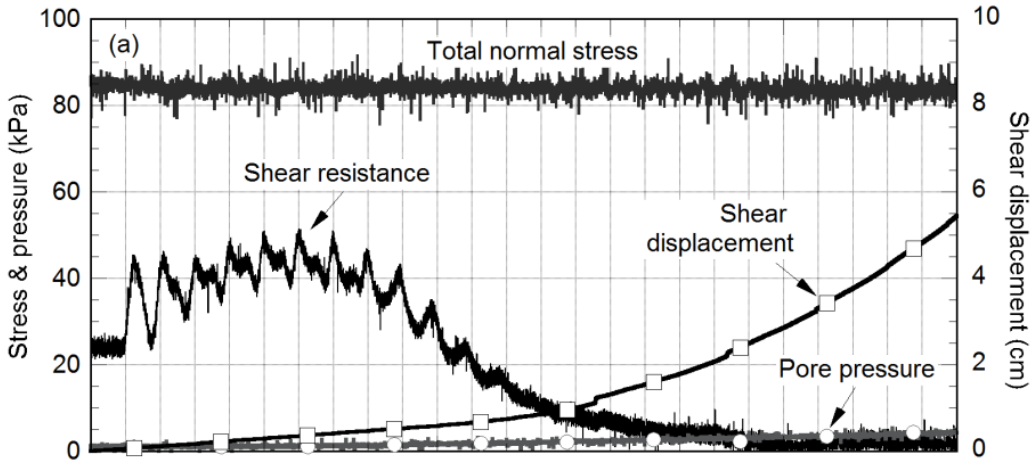

740

741

742

743

744

745

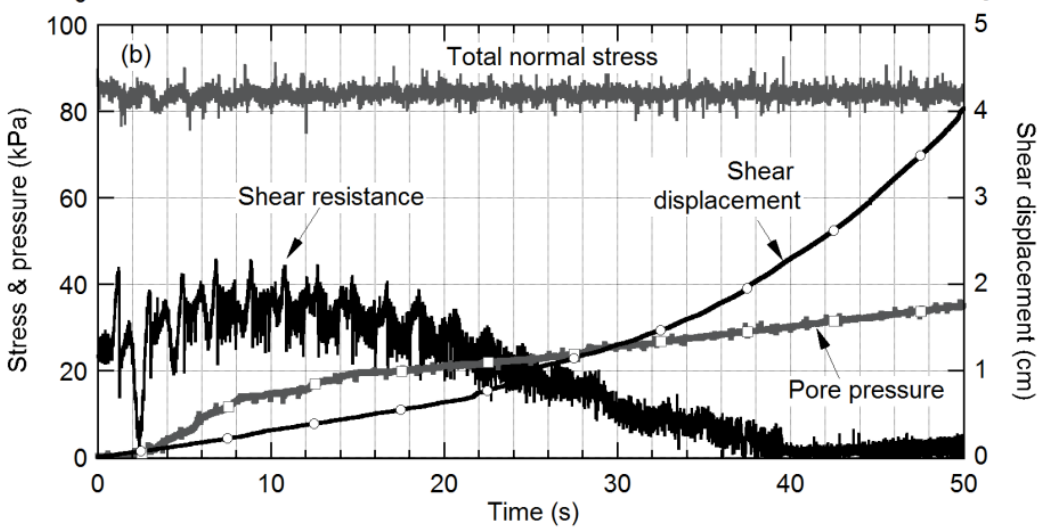

746

747

Fig. 9.

748

749

750 

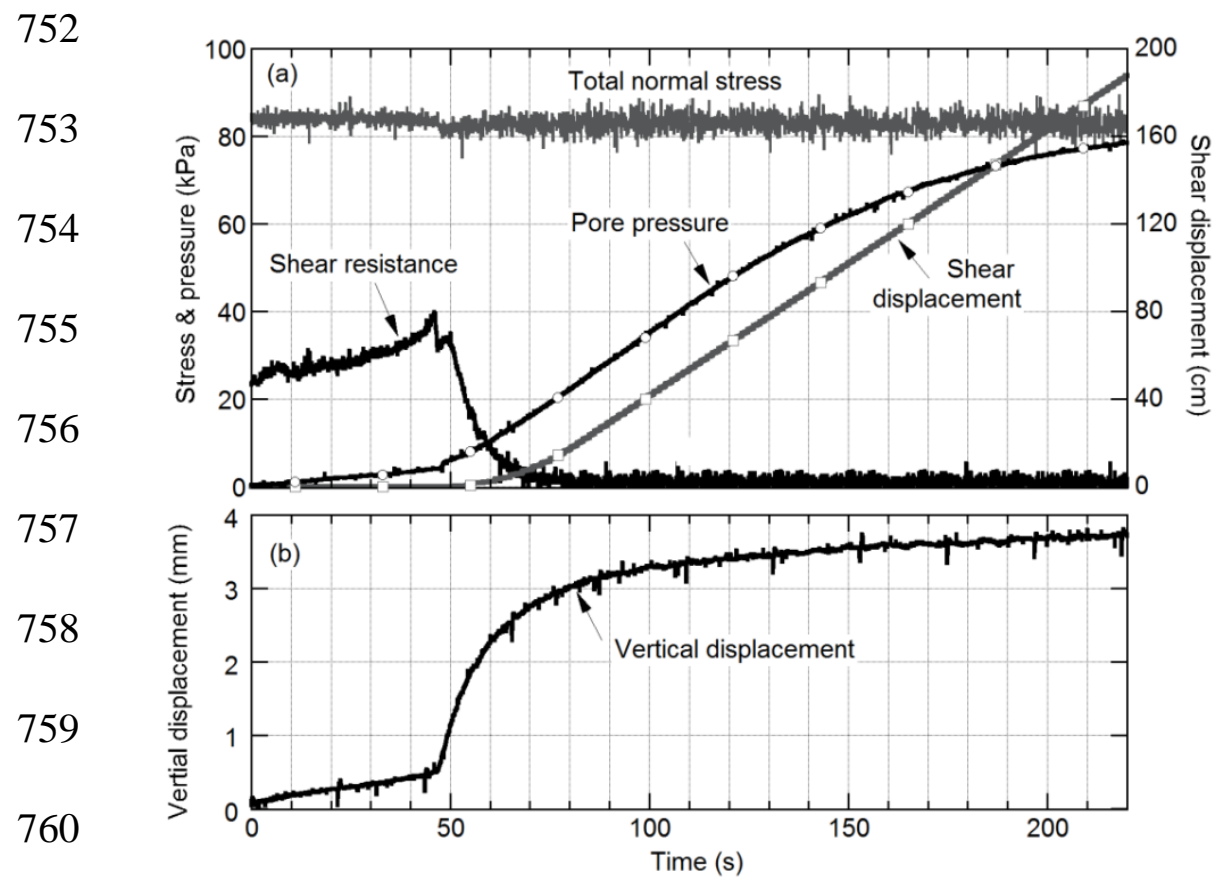

761

762

763 Fig. 10 


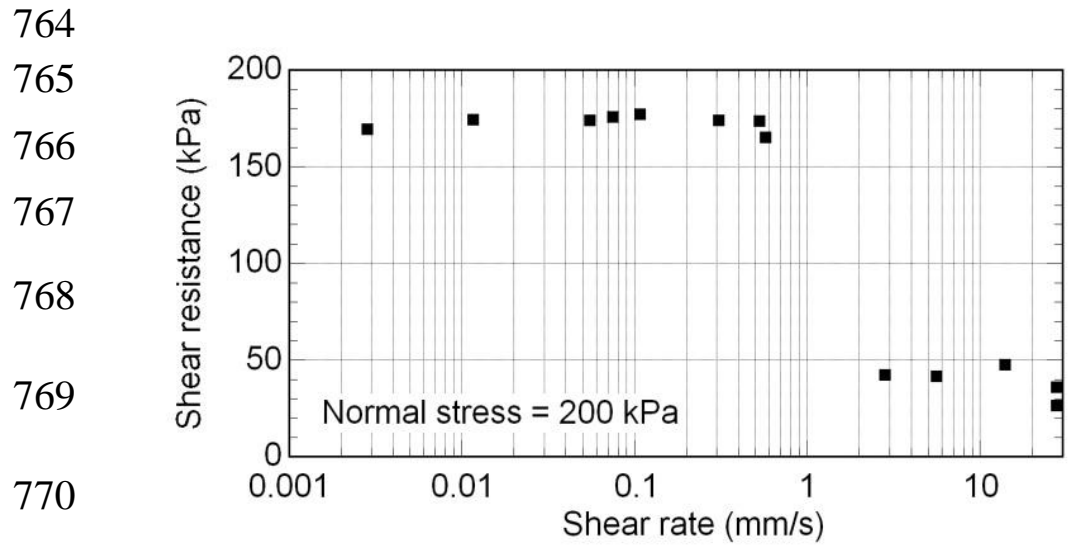

$771 \quad$ Fig. 11

772

773

774

775

776

777

778

779

780

781

782

783 